\title{
Advanced glycation end product (AGE)-induced proliferation of HEL cells via receptor for AGE-related signal pathways
}

\author{
JU YOUNG KIM ${ }^{1}$, HYUN KI PARK ${ }^{1}$, JIN SUN YOON ${ }^{1}$, SEO JU KIM ${ }^{1}$, EUN SHIL KIM ${ }^{1}$, \\ KWANG SUNG AHN ${ }^{1}$, DONG-SUN KIM ${ }^{2}$, SUNG SOO YOON ${ }^{1}$, BYOUNG KOOK KIM ${ }^{1}$ and YOUNG YIUL LEE ${ }^{1,2}$ \\ ${ }^{1}$ Cancer Research Institute, Seoul National University College of Medicine, Seoul National University \\ Hospital, Seoul; ${ }^{2}$ Department of Internal Medicine, Han Yang University Hospital, Seoul, Korea
}

Received April 2, 2008; Accepted June 3, 2008

DOI: 10.3892/ijo_00000032

\begin{abstract}
This study investigated whether advanced glycation end products (AGE) and RAGE (receptor for AGE) are involved in the proliferation of leukemia cells. AGE strongly induced the proliferation of primary acute myeloid leukemia (AML) cells and cell lines. MAP kinase, PI3K and JAK/STAT pathways were involved in cellular proliferation of HEL cells by AGE. RAGE antisense S-ODN effectively inhibited cell growth, induced apoptosis and reversed AGE-induced expression of targeting molecules in HEL cells. The study demonstrated for the first time that AGE directly induced human AML cell proliferation via the MAPK, PI3K and JAK/STAT pathways.
\end{abstract}

\section{Introduction}

Advanced glycation end products (AGE) are permanently modified protein derivatives formed in the presence of reducing sugars, such as glucose and fructose by non-enzymatic glycation, oxidation reactions and dehydration $(1,2)$.

The AGE-binding receptor family includes many members and can be broadly divided into two groups: one associated with increased oxidant stress, growth and inflammatory effects which is best represented by the receptor for AGE (RAGE), and the other associated with AGE detoxification which includes scavenger receptors, class A type II, class B type I and AGE receptors 1, 2 and 3 (3-8).

RAGE is expressed at low levels in normal tissue. In contrast, RAGE expression is upregulated in tissues where AGE accumulates such as in diabetes or in the elderly (6).

Correspondence to: Professor Young Yiul Lee, Division of Hematology/Oncology, Department of Internal Medicine, Han Yang University Hospital, 17 Haeng Dang-dong, Sung Dong-ku, Seoul 133-792, Korea

E-mail: leeyy@hanyang.ac.kr

Key words: advanced glycation end product, acute myeloid leukemia, RAGE antisense S-ODN, cell proliferation, MAP kinase, apoptosis
Although RAGE is not central to the pathogenesis of disorders, RAGE-mediated cellular activation through the MAPK kinase cascade, activation of NF- $\mathrm{KB}$ and Rho family small G-proteins, $\mathrm{cdc} 42 / \mathrm{Rac}$, is implicated in the pathogenesis of inflammatory disorders and tumor growth and metastasis (9-12).

Several studies have been published on the relationship between RAGE expression and cancer. In renal cell carcinoma, RAGE is associated with cancer cell growth, and RAGE upregulation is also associated with the invasiveness of colon and gastric cancer (13-15).

However, the effects of AGE and RAGE on human acute myeloid leukemia (AML) have not been elucidated. Thus, in the present study, we investigated whether AGE and RAGE are involved in the proliferation of AML cells.

\section{Materials and methods}

Reagents. PD098059 (an ERK inhibitor) and SB203580 (a p38 inhibitor) were purchased from Calbiochem (San Diego, CA, USA). AG490 (a JAK/STAT inhibitor) and LY294002 (a PI3K inhibitor) were purchased from Cell Signaling Technology (Beverly, MA, USA). PD098059, SB203580, LY294002 and AG490 were dissolved in DMSO (Sigma Chemical, St. Louis, $\mathrm{MO}, \mathrm{USA}$ ) and stored at $-20^{\circ} \mathrm{C}$ until their use.

Cell culture conditions and treatments. The human myeloid leukemia cell lines used in this study were KCL22, U937, KG-1, Meg01, K562, KU812, HEL, ML-1, NB4 and HL-60, which were kindly provided by Dr Koeffler (UCLA, Cedars-Sinai Medical Center, Los Angeles, CA, USA). All cell lines were routinely maintained in RPMI-1640 at $37^{\circ} \mathrm{C}$ in a $5 \% \mathrm{CO}_{2}$ /air atmosphere. Normal peripheral blood (PB MNCs) and bone marrow mononuclear cells (BM MNCs) of healthy volunteers were isolated using density-gradient centrifugation with Ficoll-Hypaque (Amersham Biosciences AB, Sweden). Human AML cells used in this study were provided by the Seoul National University Hospital. Cells were serum starved for $24 \mathrm{~h}$ and then treated with AGE (at the indicated doses), RAGE antisense S-ODN $(0.01 \mu \mathrm{M})$, PD98059 $(10 \mu \mathrm{M})$, SB203580 $(5 \mu \mathrm{M})$, LY294002 $(10 \mu \mathrm{M})$ or AG490 $(10 \mu \mathrm{M})$ for the indicated times.

AGE-receptor gene expression by reverse transcriptasepolymerase chain reaction (RT-PCR) in leukemia cell lines. 
Total cellular RNA was isolated using Trizol reagent (Molecular Research Center) at each time point. For RT reactions, $1 \mu \mathrm{g}$ of total RNA was mixed with $0.5 \mu \mathrm{g}$ of oligo $\mathrm{d}(\mathrm{T}), 10 \mathrm{mM}$ each dNTPs, $1 \mu \mathrm{g}$ RNase II, RT buffer $(50 \mathrm{mM}$ Tris-Cl, pH 8.3, $30 \mathrm{mM} \mathrm{KCl,} 8 \mathrm{mM} \mathrm{MgCl}_{2}$, and $10 \mathrm{mM}$ dithiothreitol) and 1 unit AMV Reverse transcriptase (Dakara Bio Inc.). Specific primers for AGE-R1, AGE-R2, AGE-R3, CD36 and RAGE were designed from known GenBank accession nos. (AG-R1 XM_001844, AGE-R2 NM_002743, AGE-R3 BC001120, CD36 S67532 and RAGE BC020669).

Preparation of AGE. AGE was prepared using a modification of the protocol described by Dukic-Stefanovic et al (16). Briefly, BSA fraction V (1 mM) was glycated by incubating with $0.5 \mathrm{M}$ glucose in $50 \mathrm{mM}$ potassium phosphate ( $\mathrm{pH} 7.3$ ) $/ 1 \mathrm{mM}$ EDTA under sterile conditions at $37^{\circ} \mathrm{C}$ for 8 weeks. Reaction mixtures were dialyzed against phosphate-buffered saline (PBS) to remove free glucose and were passed through a specific column (Pierce) to remove endotoxin. The AGE obtained was stored at $-20^{\circ} \mathrm{C}$ until used. Protein concentrations were determined using a Bradford-based assay (Bio-Rad Laboratories, Richmond, CA) (17).

Cell proliferation. The in vitro proliferative effect of AGE on leukemia cells was determined by measuring the MTT [3(4,5-dimethylthiazol-2-yl)-2,5 diphenyltetrazolium bromide] dye absorbance of living cells (18).

Cell cycle analysis. Cell cycle distributions were determined by staining DNA with propidium iodide (PI, Sigma), as previously described (19). The percentages of cells in the different phases of the cell cycle were determined using a FACStar flow cytometer (Becton-Dickinson, San Jose, CA) and Becton Dickinson software (Lysis II, Cellfit). The sub- $\mathrm{G}_{1}$ population was considered to be composed of apoptotic cells.

Western blot analysis. Samples containing $20 \mu \mathrm{g}$ of total protein were resolved on $12 \%$ SDS-PAGE gels, transferred to nitrocellulose membranes (Bio-Rad, Hercules, CA) by electroblotting, and probed with anti-RAGE, anti-p-p38, antip-38, anti-IкB- $\alpha$, anti-NF- $\mathrm{B}$, anti-p27, anti-PARP, anticaspase 3, 8 and 9, anti-CDK4, 6 and 2, anti-cyclin D1, E, A, anti-PCNA, anti- $\alpha$-tubulin and anti-E2F antibodies (Santa Cruz Biotechnology, Santa Cruz, CA, USA); anti-Bcl2 (Dako, Denmark); and anti-p-ERK, anti-ERK, anti-p-AKT, antipSTAT and anti-ß-actin (Cell Signaling). Blots were developed using ECL kits (Intron, Seoul, Korea) and detected by chemiluminescence.

Immunoprecipitation. Samples of total protein $(100 \mu \mathrm{g})$ were incubated with anti-CDK2 polyclonal antibodies for $2 \mathrm{~h}$ at $4^{\circ} \mathrm{C}$, and then with protein A-agarose conjugates (Santa Cruz Biotechnology) for $1 \mathrm{~h}$. The protein complexes so obtained were washed three times with immunoprecipitation buffer [50 mM Tris (pH 7.5), 0.5\% NP40, $150 \mathrm{mM} \mathrm{NaCl}, 50 \mathrm{mM}$ $\mathrm{NaF}, 0.2 \mathrm{mM} \mathrm{NaVO}_{4}, 1 \mathrm{mM}$ DTT, $20 \mu \mathrm{g} / \mathrm{ml}$ aprotinin, $20 \mu \mathrm{g} /$ $\mathrm{ml}$ leupeptin and $1 \mathrm{mM}$ phenylmethylsulfonyl fluoride] and released from agarose beads by boiling in $2 \mathrm{X}$ SDS sample buffer [125 mM Tris (pH 6.8), 4\% SDS, 10\% $\beta_{2}$-mercaptoethanol, $2 \%$ glycerol and $0.004 \%$ bromophenol blue] for
A

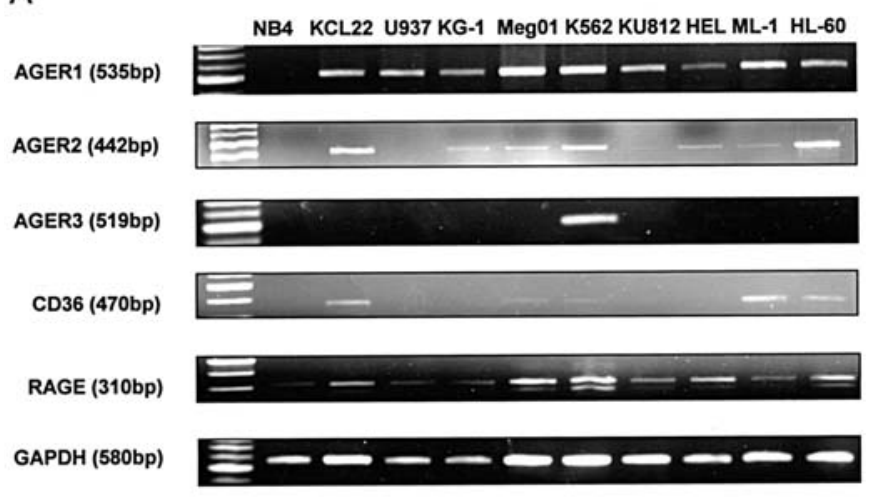

B RAGE

$\beta$-actin

NB4 KCL22 U937 KG-1 Meg01 K562 KU812 HEL ML-1 HL-60

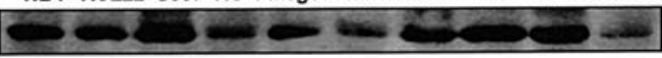

Figure 1. Expression of AGE receptors in human myeloid leukemia cell lines. (A) Messenger RNA was detected by RT-PCR. GAPDH mRNA was amplified as an internal control. (B) RAGE protein was detected by Western blotting as described in Materials and methods. Experiments were performed three times with similar results.

5 min. Reaction mixtures were resolved on $12 \%$ SDS-PAGE gels, transferred onto nitrocellulose membranes by electroblotting, and probed with anti-cyclin D1, anti-cyclin E and anti-p27 antibodies (Santa Cruz Biotechnology). Blots were developed using ECL kits.

Kinase reaction assay. Total lysates were prepared and immunoprecipitated with anti-CDK2 polyclonal antibody (Santa Cruz Biotechnology), as described above. The phosphorylated proteins were detected by autoradiography.

Antisense phosphorothioate (S)-oligodeoxynucleotide assay. The 18-mer S-oligodeoxynucleotide (ODN) for the antisense sequence of the 6th to 23rd nucleotides of RAGE cDNA (GenBank AB036432) were synthesized and purified by reverse-phase high-performance liquid chromatography (HPLC; Bioneer, Seoul) $(14,20)$. The sequence of antisense RAGE was 5'-CTG CTT CCT TCC AGG GTC-3'. The sense sequence 18-mer was used as the negative control. Cells were transfected with various concentrations of RAGE antisense S-ODN and Lipofectamine ${ }^{\mathrm{TM}}$ reagent (Invitrogen, Cergy Pontoise, France) according to the manufacturer's instructions for $24 \mathrm{~h}$ before AGE treatment.

Statistical analysis. The Student's t-test was used to analyze MTT assay results. In all analyses, P-values $<0.05$ were considered statistically significant.

\section{Results}

Expression of AGE receptors in human myeloid leukemia cell lines. To investigate whether human myeloid leukemia cells express AGE receptors, RT-PCR and Western blotting were used. RT-PCR results for AGE-R1, 2 and 3, Type II receptor 
A

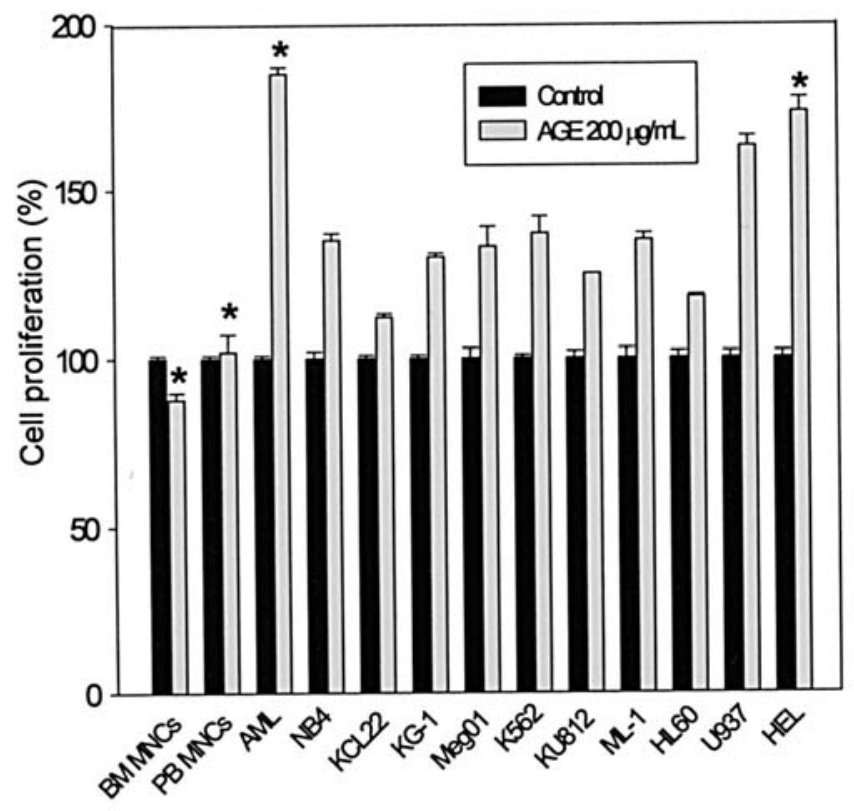

B

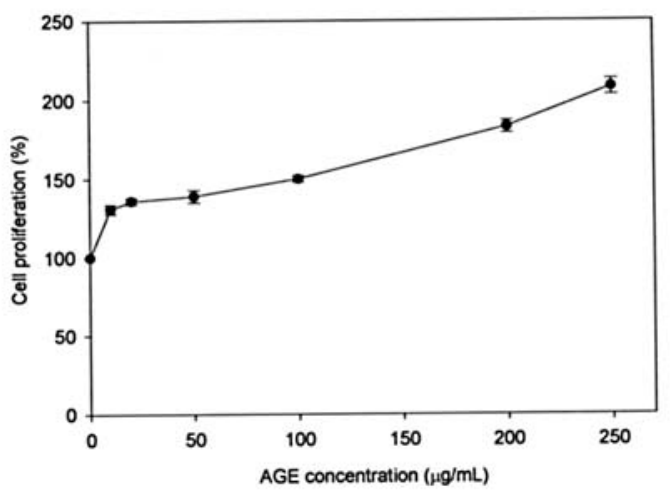

C

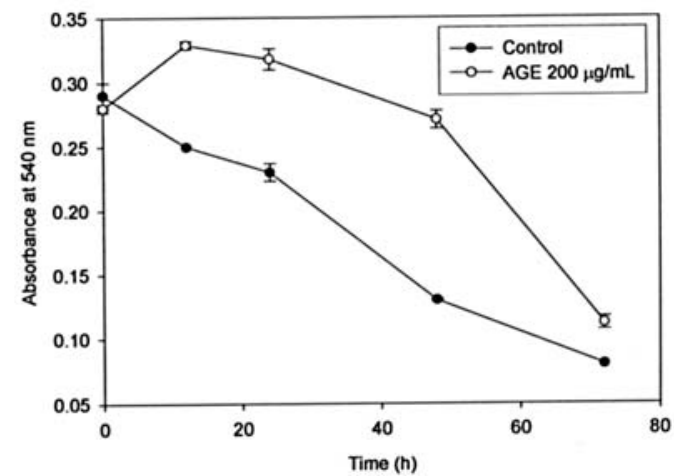

Figure 2. Effect of AGE on the proliferation of human myeloid leukemia and normal mononuclear cells. (A) Normal BM MNCs, PB MNCs, primary AML cells and myeloid leukemia cells were treated with $200 \mu \mathrm{g} / \mathrm{ml} \mathrm{AGE}$ for $24 \mathrm{~h}$. (B) HEL cells were treated with $10-250 \mu \mathrm{g} / \mathrm{ml}$ AGE for $24 \mathrm{~h}$. (C) HEL cells were treated with $200 \mu \mathrm{g} / \mathrm{ml} \mathrm{AGE}$ for $72 \mathrm{~h}$. Cell growth was assessed using MTT assay. Control viabilities were set at 100\%, and results were expressed as percentages versus controls. The significance of the cell growth was determined using the Student's t-test; ${ }^{*} \mathrm{P}<0.05$, significant difference. Results represent the means of at least 3 independent experiments; bar, SD.

(CD36) and RAGE in human myeloid leukemia cells are shown in Fig. 1A. The PCR products of AGE-R1 and RAGE were detected in all myeloid leukemia cell lines. A fragment of AGE-R2 mRNA was also detected in all myeloid leukemia cell lines except U937, and a fragment of CD36 mRNA was detected in KCL22, Meg01, K562, ML-1 and HL-60 cells. However, the PCR product of AGE-R3 was found in chronic myeloid leukemia K562 cells only. As shown in Fig. 1B, the expression of RAGE protein was observed in all leukemia cell lines examined by Western blot analysis.

Effect of AGE on the proliferation of human myeloid leukemia and normal mononuclear cells. We examined the effect of AGE on the proliferation of human myeloid leukemia cell lines using MTT assay. Cellular proliferation was noted in all leukemia cell lines after treatment with $200 \mu \mathrm{g}$ of AGE for $24 \mathrm{~h}$ (Fig. 2A), but BSA did not induce the proliferation of any leukemia cells (data not shown). A significant dose-dependent proliferation of cell growth was observed in HEL cells which showed the highest RAGE expression (Fig. 2B). When HEL cells were treated with AGE $(200 \mu \mathrm{g} / \mathrm{ml})$ for $72 \mathrm{~h}$, a growth response was observed (Fig. 2C), characterized by a significant early proliferation $(<24 \mathrm{~h})$ and a later inhibition of proliferation after $48 \mathrm{~h}$. Furthermore, cellular proliferation of primary AML cells was observed $24 \mathrm{~h}$ after treatment with
AGE (Fig. 2A) in a dose-dependent manner. In contrast, AGE did not affect the proliferation of normal PB MNCs or BM MNCs (Fig. 2A).

Effect of AGE on the cell cycle and its regulatory proteins in HEL cells. The effect of AGE on the cell cycle was determined in HEL cells using FACS analysis. As shown in Fig. 3A, HEL cells exhibited a significant dose-dependent increase in the number of cells in the $\mathrm{S}$ phase of the cell cycle after exposure to AGE (10-200 $\mu \mathrm{g} / \mathrm{ml})$ for $24 \mathrm{~h}$. Compared to untreated control cells, the percentages of cells in the $\mathrm{S}$ phase increased by $\sim 50 \%$ at an AGE concentration of $200 \mu \mathrm{g} / \mathrm{ml}$. Eukaryotic cell cycle progression is regulated by a series of cyclin-dependent kinases (CDKs), and their activities are positively regulated by cyclins and negatively regulated by cyclin-dependent kinase inhibitors (CDKIs) (21-24). The treatment of HEL cells with $200 \mu \mathrm{g} / \mathrm{ml}$ of AGE for $24 \mathrm{~h}$ resulted in the upregulation of cyclin D1, E and A, CDK2, 4 and 6, PCNA, and E2F in a dose-dependent manner, whereas the levels of CDKI, p27 were dose-dependently downregulated (data not shown). In addition, the complexes immunoprecipitated by anti-cyclin D1 and E antibodies exhibited higher amounts of immunodetectable CDK2 protein from AGE-treated cells than from control cells. Furthermore, the amount of $\mathrm{p} 27 / \mathrm{CDK} 2$ complex was reduced in a dose- 
A

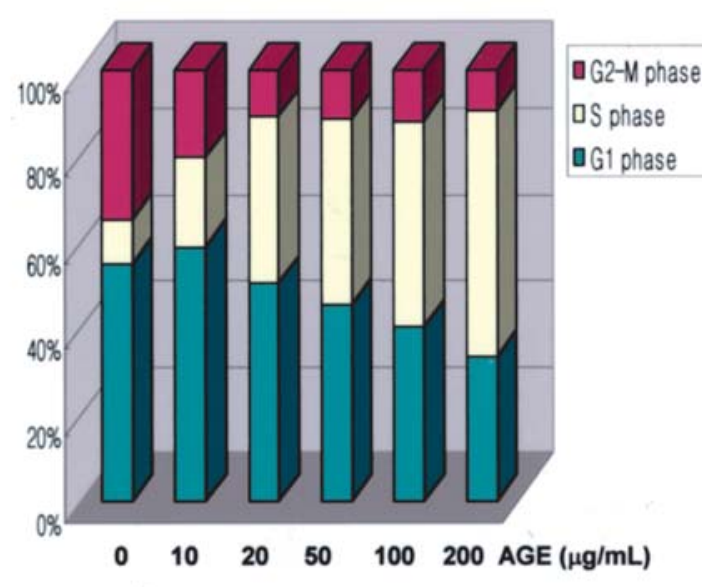

B IP:

CDK2

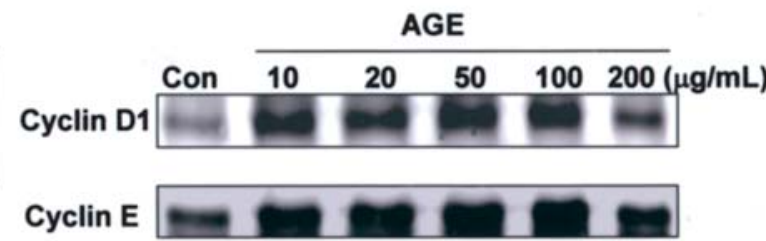

p27

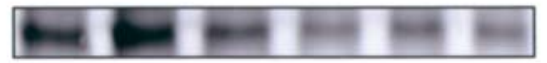

IgG

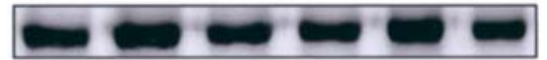

C

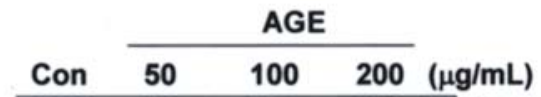

CDK2

Figure 3. Effect of AGE on the cell cycle and cell cycle regulatory proteins in HEL cells. (A) Effect of AGE treatment on the cell cycle profile. After treatment with 10-200 $\mu \mathrm{g} / \mathrm{ml}$ of AGE for $24 \mathrm{~h}$, cells were collected, and cell cycle analyses were performed by FACS. (B) The effects of AGE on the binding of cyclin D1, cyclin E and p27 to CDK2 proteins. After treatment with 10-200 $\mu \mathrm{g} / \mathrm{ml}$ of AGE for $24 \mathrm{~h}$, total lysates were immunoprecipitated with anti-CDK2. Levels of bound cyclin D1, cyclin E, and p27 in each immunocomplex were determined by Western blot analysis. (C) CDK2 kinase activity. After treating cells with $200 \mu \mathrm{g} / \mathrm{ml}$ AGE for $2 \mathrm{~h}, \mathrm{CDK} 2$ kinase activities were determined using a histone H1 kinase assay as described in Materials and methods.

dependent manner in AGE-treated cells (Fig. 3B). Furthermore, treatment with AGE (50-200 $\mu \mathrm{g} / \mathrm{ml}$ for $24 \mathrm{~h}$ ) dramatically increased CDK2-associated kinase activity compared to untreated control cells (Fig. 3C).

Evaluation of RAGE-related signaling in AGE-treated human myeloid leukemia cell lines. RAGE interacts with a variety of extracellular stimuli including AGE, amphoterin and the S100/calgranulins (6). We were interested in identifying signaling pathways activated by AGE, especially those of MAPK, PI3K (phosphoinositide 3 kinase) and JAK/STAT (Fig. 4). The phosphorylated form of ERK was increased by incubating HEL cells with AGE in a time- and dose-dependent manner (Fig. 4A). In addition, phosphorylated p38 kinase protein was increased in a time-dependent manner. However, a brief increase in p-p38 was found to be followed by sustained dephosphorylation after $1 \mathrm{~h}$ of AGE treatment (Fig. 4B). When HEL cells were pre-treated with $10 \mu \mathrm{M}$ of PD98059 or $5 \mu \mathrm{M}$ of SB203580, and then stimulated with $200 \mu \mathrm{g} / \mathrm{ml}$ of AGE for $2 \mathrm{~h}$, the upregulation of p-ERK (Fig. 4A) and p-p38 (Fig. 4B) by AGE was abolished, respectively. PI3K is a heterodimeric lipid kinase and is thought to play a critical role in tumor cell survival when activated. As shown in Fig. 4C, AKT protein, a key downstream effector of PI3K action, was activated in AGE-treated HEL cells in a timedependent manner. This activation of AKT protein was inhibited by LY294002. Moreover, transcription factor nuclear factor of $\kappa \mathrm{B}(\mathrm{NF}-\kappa \mathrm{B})$, which can be activated by intracellular signaling (e.g. AKT activation), was increased by AGE, whereas the inhibitor of $\kappa \mathrm{B}(\mathrm{I} \kappa \mathrm{B})$, which regulates the activity of NF- $\kappa \mathrm{B}$, was reduced. Regarding the JAK/STAT pathway, phosphorylated STAT-3 and -5 were found to be upregulated dose-dependently by AGE, and c-myc protein (a nuclear target molecule of STAT) level was elevated in AGE-treated HEL cells (Fig. 4D). The phosphorylated forms of ERK, STAT-3 and AKT were also increased in U937 cells (the second highest RAGE expression 10 leukemia cell lines) treated with AGE in a time- and dose-dependent manner (Fig. 4E).

Effect of RAGE antisense S-ODN on the growth of HEL cells. AGE mediates its effects through specific receptors such as RAGE $(2,8)$. To study the effect of AS-RAGE on the growth of HEL cells, we subjected the cells to a transient transfection with antisense S-ODN for RAGE. The cells transfected with the RAGE antisense $S$-ODN $(0.01 \mu \mathrm{M}$; AS-RAGE) exhibited a marked reduction in RAGE protein levels compared with that in cells transfected with vehicle alone (Mock), sense siRNA (0.01 $\mu \mathrm{M}$; s-RAGE) and non-transfected (NT) (Fig. 5). Next, we verified the effect of AS-RAGE on the growth of HEL cells by MTT assay (Fig. 5). As expected, a marked cellular proliferation of HEL cells was observed $24 \mathrm{~h}$ after treating cells with $200 \mu \mathrm{g} / \mathrm{ml}$ of AGE. The growth of HEL cells with $0.01 \mu \mathrm{M}$ of AS-RAGE pretreatment for $24 \mathrm{~h}$ followed by $200 \mu \mathrm{g} / \mathrm{ml}$ of AGE was inhibited by $90 \%$ at $24 \mathrm{~h}$. Furthermore, incubation of HEL cells with $0.01,0.1,1$ or $5 \mu \mathrm{M}$ of S-RAGE for $24 \mathrm{~h}$ resulted in growth inhibitions of 36,31 , 25 and $50 \%$, respectively, versus untreated control cells. In contrast, S-RAGE did not affect the cellular proliferation of HEL cells. Furthermore, combined treatment of S-RAGE and AGE resulted in the additive proliferative effect of HEL cells.

Effect of AS-RAGE on cell cycle regulatory proteins and $R A G E$-related signaling pathways. Since AS-RAGE effectively inhibited HEL cell proliferation, this study investigated whether cell cycle regulators might be altered during the growth inhibition caused by AS-RAGE. Treatment of HEL cells with $200 \mu \mathrm{g} / \mathrm{ml}$ of AGE for $24 \mathrm{~h}$ enhanced the expression of CDK4 and 6, cyclin D1, E and A, PCNA, E2F and RAGE, and reduced the expression of CDKI, p27. In 

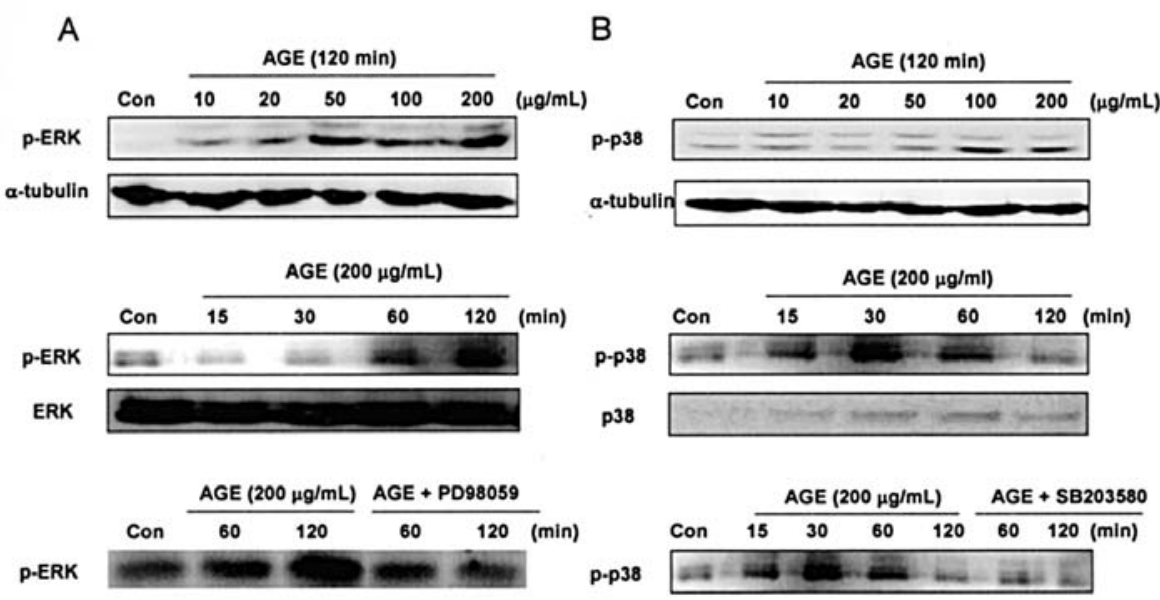

C
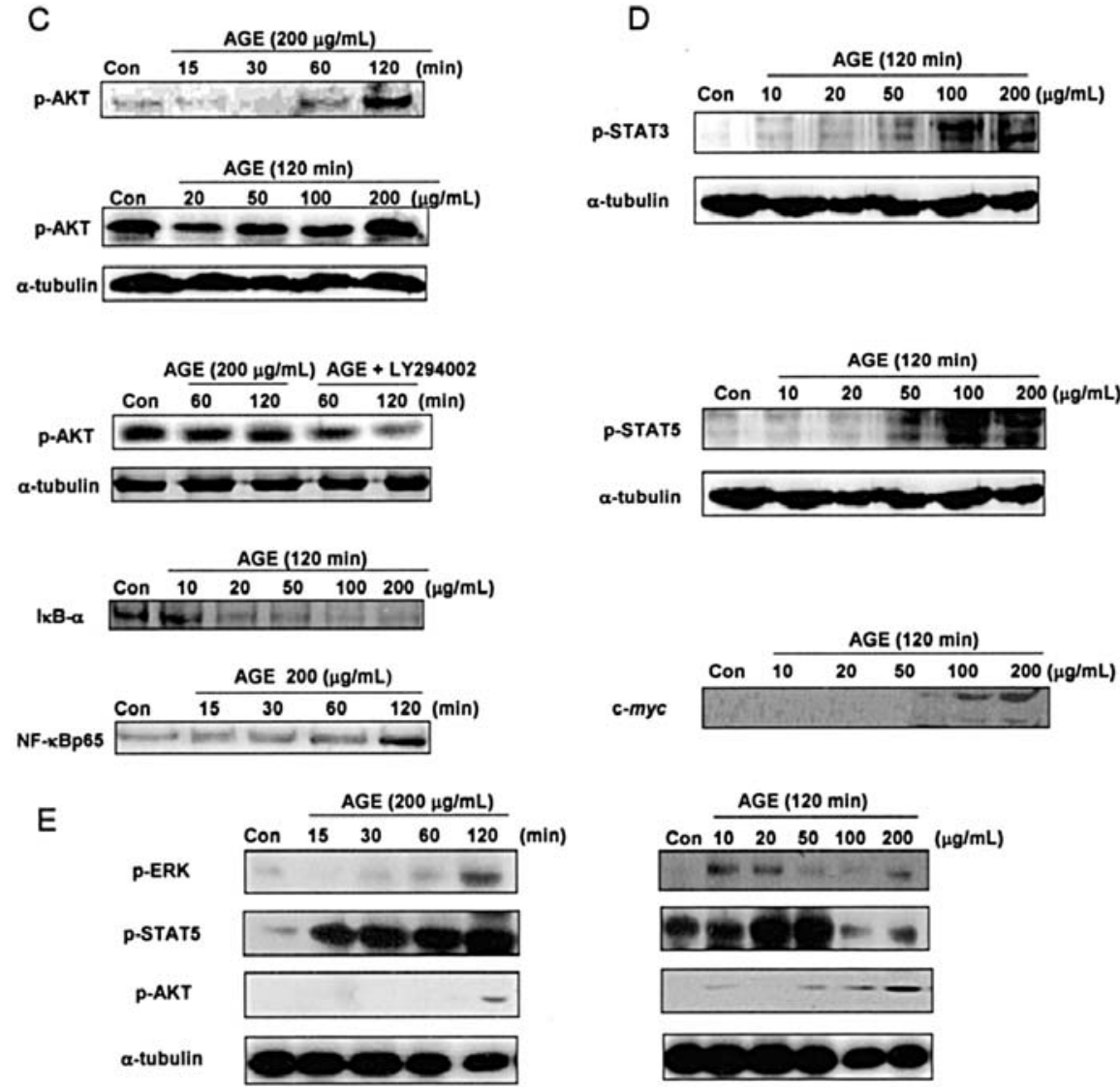

Figure 4. The evaluation of RAGE-related signaling in AGE-treated HEL, U937 and HL60 cells. (A-D) HEL cells were treated with 10-200 $\mu \mathrm{g} / \mathrm{ml}$ AGE for $2 \mathrm{~h}$, or preincubated with $10 \mu \mathrm{M}$ PD98059 or $5 \mu \mathrm{M} \mathrm{SB} 203580$, or $10 \mu \mathrm{M} \mathrm{LY} 294002$ for $30 \mathrm{~min}$ and stimulated with $200 \mu \mathrm{g} / \mathrm{ml}$ AGE for $2 \mathrm{~h}$. (E) U937 cells were treated with 10-200 $\mu \mathrm{g} / \mathrm{ml} \mathrm{AGE}$ for $2 \mathrm{~h}$. After electroblotting, blots were incubated with specific antibodies. The data shown are from three representative experiments.

contrast, these expressional changes were reversed by transfection with $0.01 \mu \mathrm{M}$ of AS-RAGE for $24 \mathrm{~h}$ (Fig. 6A).

CDK2 is a small serine/threonine kinase that regulates cell cycle progression (21-24), and as described above, the activity of CDK2-associated kinase was increased by AGE treatment. However, treatment of cells with $0.01 \mu \mathrm{M}$ of ASRAGE for $24 \mathrm{~h}$ before a 24-h incubation with AGE resulted in a significant reduction in CDK2-associated kinase activity (Fig. 6A). In this experiment, major signal transduction pathways, including MAPK, PI3K and JAK/STAT were found to be necessary for AGE-induced HEL proliferation. In order to further investigate the possibility that the AGEdependent proliferative response is mediated via these pathways, the effects of AS-RAGE on important target molecules (ERK, p38, AKT and STAT-3) in these pathways was evaluated (Fig. 6B and C). Pretreatment with AS-RAGE $(0.01 \mu \mathrm{M})$ for $24 \mathrm{~h}$ inhibited the AGE-induced expression of p-ERK, p-p38 and p-AKT. Furthermore, NF-кB activation (NF- $\mathrm{KB}$ can be activated by P-AKT) was reduced by ASRAGE (Fig. 6B). A similar result was observed for STAT-3 


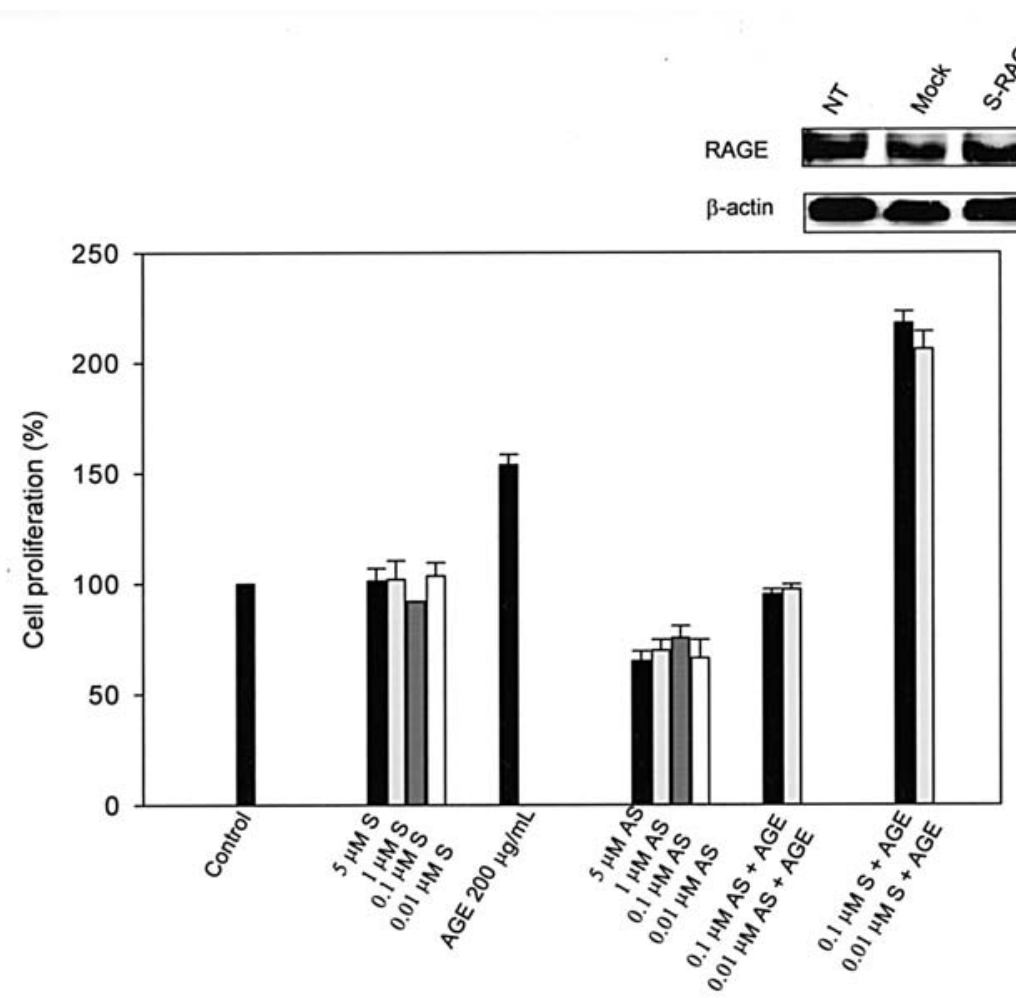

Figure 5. Effect of AS-RAGE on HEL cell growth. Knockdown of RAGE protein levels by antisense S-ODN. At $24 \mathrm{~h}$ post transfection, whole cell lysates from HEL cells transfected with vehicle alone (Mock), RAGE S-oligodeoxynucleotide ( $0.01 \mu \mathrm{M}$; s-RAGE), RAGE antisense-oligodeoxynucleotide ( $0.01 \mu \mathrm{M}$; AS-RAGE) and non-transfected (NT), were subjected to immunoblotting with the anti-RAGE and anti-ß-actin Ab as loading control. Blots are representative of three independent experiments. Then, cells were treated with $200 \mu \mathrm{g} / \mathrm{ml} \mathrm{AGE}, 0.01-5 \mu \mathrm{M}$ sense S-ODN, $0.01-5 \mu \mathrm{M}$ AS-RAGE for $24 \mathrm{~h}$, preincubated with 0.1-0.01 $\mu \mathrm{M} \mathrm{S-RAGE} \mathrm{for} 24 \mathrm{~h}$ before AGE treatment, or preincubated with 0.1-0.01 $\mu \mathrm{M}$ AS-RAGE for $24 \mathrm{~h}$ before AGE treatment. Cell growth was determined by MTT assays, as described in Materials and methods. Results represent the means of at least 3 independent experiments; bar, SD.

(Fig. 6C). In addition, pre-treatment of HEL cells with $10 \mu \mathrm{M}$ of AG490 for 30 min and subsequent treatment with $200 \mu \mathrm{g} /$ $\mathrm{ml}$ of AGE for $2 \mathrm{~h}$ inhibited AGE-enhanced STAT-3 phosphorylation (Fig. 6C).

Effect of RAGE antisense S-ODN on induction of apoptosis and apoptotic-related proteins in HEL cells. Since cell growth was inhibited by AS-RAGE, this study performed in vitro apoptosis detection assays to determine whether AS-RAGE induces apoptosis in HEL cells by FACS. Apoptosis was induced in a time-dependent manner by treatment with $0.01 \mu \mathrm{M}$ of AS-RAGE for $48 \mathrm{~h}$ (Fig. 7A). In particular, the percentage of apoptotic cells was found to be $\sim 39 \%$ at $48 \mathrm{~h}$. In addition, activation of caspase- 3 was associated with the induction of apoptosis by AS-RAGE. The expression of 32-kDa precursor (effector caspase-3 proform) was reduced after treatment with $0.01 \mu \mathrm{M}$ AS-RAGE (Fig. 7B), and initiator procaspase-9 was inhibited. Regarding PARP protein, a major substrate of executor caspases and a hallmark of apoptosis, Western blotting showed that $113-\mathrm{kDa}$ PARP was degraded, as evidenced by an increase in the $89-\mathrm{kDa}$ cleavage product in AS-RAGE-treated HEL cells. Concerning the relationship between Bcl-2 and Bax during AS-RAGE-induced apoptosis, Bcl-2 was reduced (Fig. 7B), but Bax was constitutively expressed at an unchanged protein level (data not shown). The expression of caspase- 8 was also unaltered during apoptosis.

\section{Discussion}

This study investigated the proliferative effect of AGE on AML cells. AGE is known to induce a variety of cellular events, including inflammatory response and cellular proliferation, possibly by interacting with several functional AGE receptors, thereby modulating disease progression (2-8). We demonstrated that RAGE mRNA and protein were expressed in all leukemia cell lines examined by RT-PCR and Western blotting.

AGE induced the proliferation of AML cell lines as well as primary AML cells. In contrast, proliferation of $\mathrm{PB}$ or $\mathrm{BM}$ MNCs was not affected by AGE treatment. These results suggest that AGE may selectively act on leukemia cells.

Additionally, the cell proliferation assay was performed for $72 \mathrm{~h}$ in HEL cells which expressed high levels of RAGE. Treatment of HEL cells with AGE significantly increased cell proliferation compared to control cells until $72 \mathrm{~h}$ in serum-free conditions. Cellular proliferation at $200 \mu \mathrm{g} / \mathrm{ml}$ peaked at $12 \mathrm{~h}$ in HEL cells and then subsided.

Although unclear, our HEL cells proliferated generally in serum-containing medium. To exclude any potential effects of serum, the cell proliferation assay was carried out in serum-free condition. Thus, decreased OD values of HEL cells might have been due to a serum-free condition.

AGE-induced HEL proliferation was found to be associated with cell cycle progression. Cell cycle analysis revealed that 
A

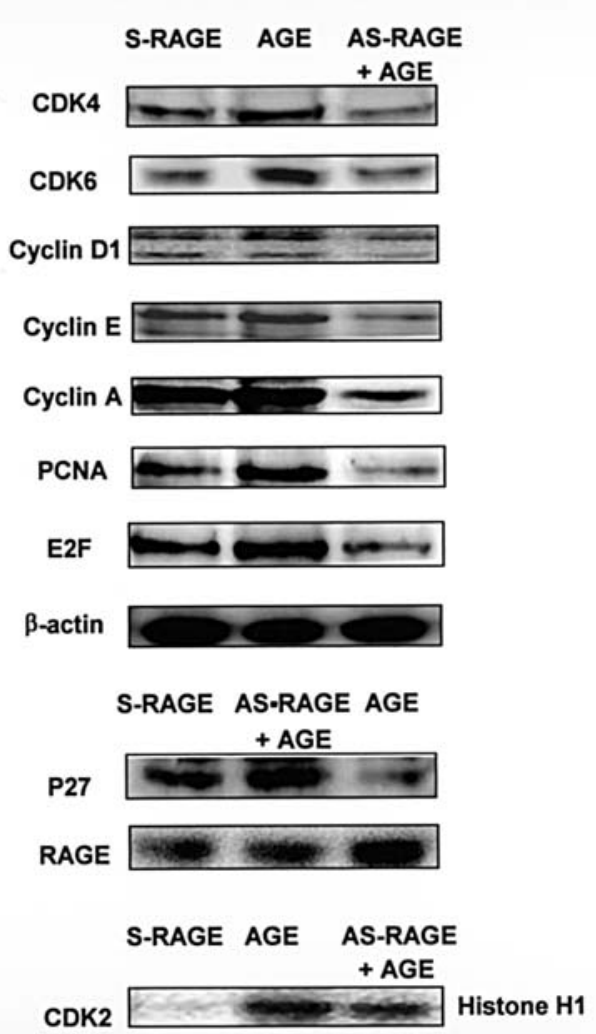

B
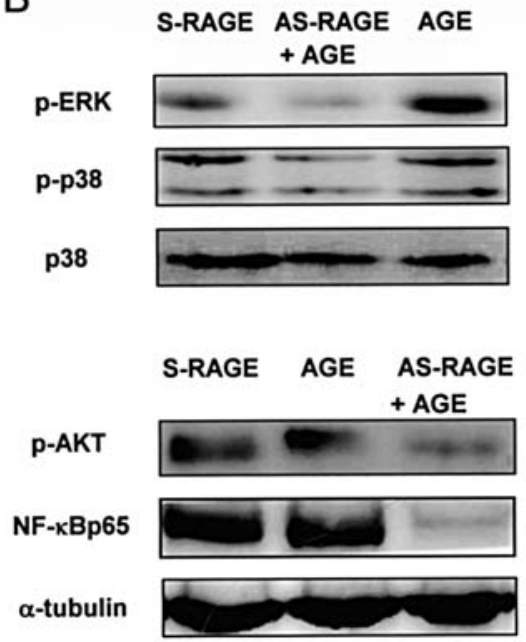

C

AGE $(200 \mu \mathrm{g} / \mathrm{mL})$

S-RAGE AG490 AGE AG490 AS-RAGE

p-STAT3

$\beta$-actin

Figure 6. Effect of AS-RAGE on cell cycle regulatory proteins and RAGE-related signaling pathways. (A) HEL cells were treated with $0.01 \mu$ M S-RAGE (used as a positive control), $200 \mu \mathrm{g} / \mathrm{ml}$ AGE for $2 \mathrm{~h}$ or $0.01 \mu \mathrm{M}$ AS-RAGE for $24 \mathrm{~h}$ before a 24-h incubation with AGE. Expression of cell cycle regulatory proteins and RAGE were analyzed by Western blotting with anti-CDK4 and 6, cyclin D1, E and A, PCNA, E2F, p27 and RAGE. CDK2 kinase activity was determined using histone $\mathrm{H} 1$ kinase assays, as described in Materials and methods. (B) HEL cells were treated with $0.01 \mu \mathrm{M} \mathrm{S}-\mathrm{RAGE}, 200 \mu \mathrm{g} / \mathrm{ml} \mathrm{AGE}$ for $2 \mathrm{~h}$, or $0.01 \mu \mathrm{M}$ AS-RAGE for $24 \mathrm{~h}$ before a 2-h incubation with AGE. RAGE-related signaling proteins were determined by Western blot analysis using specific antibodies. (C) HEL cells were treated with $0.01 \mu \mathrm{M}$ S-RAGE, $10 \mu \mathrm{M}$ AG490 for $30 \mathrm{~min}, 200 \mu \mathrm{g} / \mathrm{ml}$ AGE for $2 \mathrm{~h}, 0.01 \mu \mathrm{M}$ AS-RAGE for $24 \mathrm{~h}, 10 \mu \mathrm{M}$ AG490 for $30 \mathrm{~min}$ before being treated with $200 \mu \mathrm{g} / \mathrm{ml}$ AGE for $2 \mathrm{~h}$ or $0.01 \mu \mathrm{M}$ AS-RAGE for $24 \mathrm{~h}$ before being treated with $200 \mu \mathrm{g} / \mathrm{ml}$ AGE for $2 \mathrm{~h}$. Phosphorylation of STAT-3 was analyzed by Western blotting. Experiments were repeated three times with similar results.

A

\begin{tabular}{lcccc}
\hline & S-RAGE & $\begin{array}{c}\text { AGE 200 } \\
\mu \mathrm{g} / \mathrm{ml}\end{array}$ & $\begin{array}{c}\text { ASO.0 } \\
1 \mu \mathrm{M}\end{array}$ & $\begin{array}{c}\text { AS0.01 } \mu \mathrm{M}+ \\
\text { AGE200 } \mu \mathrm{g} / \mathrm{ml}\end{array}$ \\
\hline 1h & 1.3 & 1.3 & 1.4 & 2.6 \\
$2 \mathrm{~h}$ & 1.3 & 2.0 & 1.3 & 2.0 \\
$4 \mathrm{~h}$ & 1.8 & 2.0 & 2.2 & 2.4 \\
$12 \mathrm{~h}$ & 2.8 & 2.6 & 2.9 & 2.6 \\
$24 \mathrm{~h}$ & 4.3 & 5.3 & 19.5 & 14.0 \\
$48 \mathrm{~h}$ & 10.0 & 19.0 & 38.7 & 39.0 \\
\hline
\end{tabular}

B

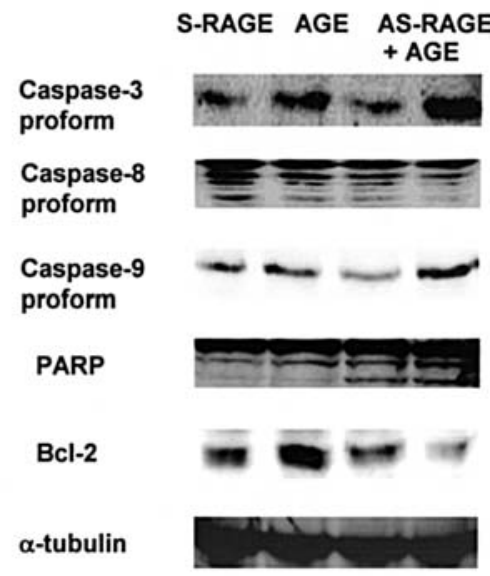

Figure 7. Effects of AS-RAGE on the induction of apoptosis and on the expression of apoptotic-related proteins in HEL cells. Cells were treated with $0.01 \mu \mathrm{M}$ sense S-RAGE (used as a positive control), $200 \mu \mathrm{g} / \mathrm{ml}$ of AGE, $0.01 \mu \mathrm{M}$ AS-RAGE or $0.01 \mu \mathrm{M}$ AS-RAGE for $24 \mathrm{~h}$ before a 24-h incubation with AGE. (A) Percentages of sub- $\mathrm{G}_{1}$ group cells by FACS analysis. (B) Modulation of apoptotic-related proteins. Caspase-3, -8, -9 , PARP, Bcl-2 were analyzed by Western blotting. The results shown are representative of at least three independent experiments.

AGE progresses the cell cycle into the S-phase in a dosedependent manner. Of the CDKs which regulate the cell cycle, CDK2, 4 and 6 are activated in association with cyclin
D or $\mathrm{E}$ during $\mathrm{G}_{1}$ progression and $\mathrm{G}_{1}-\mathrm{S}$ transition, and $\mathrm{CDK} 2$ kinase is activated primarily in association with cyclins $\mathrm{A}$ and $B$ during $\mathrm{G}_{2}-\mathrm{M}$ phase progression (21-24). In the present 
study, the protein levels of cyclin D1, -E, -A, CDK2, 4, 6, PCNA and E2F were increased in a dose-dependent manner by AGE, whereas the levels of CDKI, p27 protein were dosedependently reduced. In addition, CDK2/cyclin D1 and $\mathrm{CDK} 2 /$ cyclin $\mathrm{E}$ complexes in association with $\mathrm{G}_{1}$ progression were detected largely in AGE-treated cells. Furthermore, the observed reduction in $\mathrm{p} 27 / \mathrm{CDK} 2$ complex formation and increased CDK2-associated kinase activity support the notion that progression from $G_{1}$ into the $S$-phase is mediated by the upregulation of CDK2-associated kinase activity in association with reduction of CDKI, p27 in AGE-treated HEL cells. In particular, AGE-induced $G_{1}$ to $S$ progression was confirmed by treating HEL cells with AS-RAGE, which showed that the expression of these cell cycle regulatory molecules was reversed by $0.01 \mu \mathrm{M}$ of AS-RAGE treatment for $24 \mathrm{~h}$.

ERK and p38 are archetypal molecules of the MAPK superfamily. ERK activation is induced by response to a variety of mitogens and growth factors, and its sustained activation eventually triggers cellular proliferation (25-27). In HEL cells, AGE elicited substantial dose- and timedependent activations of ERK and p38, and these activations were inhibited by PD98059 and SB203580, respectively. These results suggest that the proliferation of HEL cells induced by AGE might be dependent upon or tightly regulated by MAPK pathway activation.

Next, the involvement of the transmembrane protein tyrosine kinase (PTK)-dependent PI3K pathway in AGEstimulated HEL cells was investigated. Activated PI3K phosphorylates the membrane lipid PIP2 to PIP3, which acts as a membrane-docking site for a number of cellular proteins including AKT. In this study, AGE induced phosphorylation of the AKT in HEL cells, and the expression of p-AKT was inhibited by LY294002, suggesting that the PI3K pathway was activated by AGE.

JAK (janus kinase), another non-receptor tyrosine kinase, phosphorylates STAT (signal transducer and activator of transcription) transcription factors, which translocate to the nucleus and activate target genes. Accumulated data indicate that the RAGE-AGE interaction is mediated via a JAK/ STAT pathway in various cell types (28). The present study also showed that AG490 and AS-RAGE reversed AGEinduced STAT3 phosphorylation in HEL cells. Thus, the JAK/ STAT pathway is involved in AGE-induced HEL proliferation.

$\mathrm{NF}-\kappa \mathrm{B}$ is known to be a positive regulator of cell cycle progression, and it activates target genes, such as cyclin D1, D2, D3 and E (29-31). NF- $\mathrm{KB}$ is also an important regulatory factor for a transcription factor, c-myc protein, which regulates a distinct set of target genes whose functions are associated with cell proliferation or apoptosis. Our results showed the upregulation of $\mathrm{NF}-\mathrm{\kappa B}$ and c-myc, and the downregulation of I $\mathrm{B}$ in AGE-treated HEL cells. These results suggest that AGE-induced proliferation of AML cells were eventually mediated via activation of NF- $\kappa \mathrm{B}$.

This study went on to examine the effect of RAGE in HEL cells, and found that AS-RAGE effectively inhibited HEL cell proliferation. This inhibition was found to be associated with the induction of apoptosis by AS-RAGE. The level of pro-caspase-3, -9 and $\mathrm{Bcl}-2$ were degraded by treatment with AS-RAGE, and the PARP protein, a major substrate for executor caspases and a hallmark of apoptosis, was degraded, as evidenced by increased levels of the 89-kDa cleavage product in AS-RAGE-treated HEL cells. In particular, caspase-8, the most proximal caspase in the Fas receptor signaling pathway, was not activated, which suggests that ASRAGE does not trigger apoptosis via Fas receptor signaling. Based on the results of this study, we speculate that the action of AGE is probably mediated via an interaction with RAGE, since RAGE attenuation by AS-RAGE was associated with the inhibition of cell proliferation by AGE.

Although this study did not completely analyze all steps along the RAGE-related pathway, it reports for the first time that AGE directly induces human AML cell proliferation. Based on this finding, we speculate that RAGE ligation by AGE may cause HEL cell proliferation via the MAPK, PI3K and JAK/STAT pathways, thus leading to the activation of nuclear transcription factors, such as NF- $\mathrm{KB}$ and c-myc, and ultimately to the triggering of the cell cycle machinery.

Finally, these results suggest that the targeting of the RAGE/AGE system may provide a new therapeutic target for the prevention and treatment of acute myeloid leukemia.

\section{Acknowledgements}

This work was supported by the Molecular and Cellular BioDiscovery Research Program grant from the Ministry of Science and Technology, South Korea. Also, this work was supported by the research fund of Hanyang University (HY2004-S), Korea.

\section{References}

1. Brownlee M, Cerami A and Vlassara H: Advanced glycosylation end products in tissue and the biochemical basis of diabetic complications. N Engl J Med 318: 1315-1321, 1988.

2. Miyata T, Hori O, Zhang J, et al: The receptor for advanced glycation end products (RAGE) is a central mediator of the interaction of AGE-beta2microglobulin with human mononuclear phagocytes via an oxidant-sensitive pathway. Implications for the pathogenesis of dialysis-related amyloidosis. J Clin Invest 98: 1088-1094, 1996.

3. Bucciarelli LG, Wendt T, Rong L, et al: RAGE is a multiligand receptor of the immunoglobulin superfamily: implications for homeostasis and chronic disease. Cell Mol Life Sci 59: 1117-1128, 2002.

4. Huttunen HJ, Fages C, Kuja-Panula J, Ridley AJ and Rauvala H: Receptor for advanced glycation end products-binding $\mathrm{COOH}-$ terminal motif of amphoterin inhibits invasive migration and metastasis. Cancer Res 62: 4805-4811, 2002.

5. Mazurek N, Conklin J, Byrd JC, Raz A and Bresalier RS: Phosphorylation of the beta-galactoside-binding protein galectin-3 modulates binding to its ligands. J Biol Chem 275: 36311-36315, 2000

6. Li YM, Mitsuhashi T, Wojciechowicz D, et al: Molecular identity and cellular distribution of advanced glycation endproduct receptors: relationship of p60 to OST-48 and p90 to $80 \mathrm{~K}-\mathrm{H}$ membrane proteins. Proc Natl Acad Sci USA 93: 11047-11052, 1996.

7. Hirai M and Shimizu N: Purification of two distinct proteins of approximate Mr 80,000 from human epithelial cells and identification as proper substrates for protein kinase C. Biochem J 270: 583-589, 1990

8. Stern DM, Yan SD, Yan SF and Schmidt AM: Receptor for advanced glycation endproducts (RAGE) and the complications of diabetes. Ageing Res Rev 1: 1-15, 2002.

9. Bierhaus A, Schiekofer S, Schwaninger M, et al: Diabetesassociated sustained activation of the transcription factor nuclear factor-kappaB. Diabetes 50: 2792-2808, 2001.

10. Lander HM, Tauras JM, Ogiste JS, Hori O, Moss RA and Schmidt AM: Activation of the receptor for advanced glycation end products triggers a p21(ras)-dependent mitogen-activated protein kinase pathway regulated by oxidant stress. J Biol Chem 272:17810-17814, 1997. 
11. Schmidt AM, Hasu M, Popov D, et al: Receptor for advanced glycation end products (AGEs) has a central role in vessel wall interactions and gene activation in response to circulating AGE proteins. Proc Natl Acad Sci USA 91: 8807-8811, 1994.

12. Schmidt AM, Hori O, Brett J, Yan SD, Wautier JL and Stern D: Cellular receptors for advanced glycation end products. Implications for induction of oxidant stress and cellular dysfunction in the pathogenesis of vascular lesions. Arterioscler Thromb 14: 1521-1528, 1994

13. Miki S, Kasayama S, Miki Y, Nakamura Y, Yamamoto M, Sato B, et al: Expression of receptors for advanced glycosylation end products on renal cell carcinoma cells in vitro. Biochem Biophys Res Commun 196: 984-989, 1993.

14. Kuniyasu H, Chihara Y and Kondo H: Differential effects between amphoterin and advanced glycation end products on colon cancer cells. Int J Cancer 104: 722-727, 2003.

15. Kuniyasu H, Oue N, Wakikawa A, Shigeishi H, Matsutani N, Kuraoka K, et al: Expression of receptors for advanced glycation end-products (RAGE) is closely associated with the invasive and metastatic activitiy of gastirc cancer. J Pathol 196: 163-170, 2002.

16. Dukic-Stefanovic S, Gasic-Milenkovic J, Deuther-Conrad W and Munch G: Signal transduction pathways in mouse microglia $\mathrm{N}-11$ cells activated by advanced glycation endproducts (AGEs). J Neurochem 87: 44-55, 2003

17. Abe H, Matsubara T, Iehara N, Nagai K, Takahashi T, Arai H, et al: Type IV collagen is transcriptionally regulated by Smad1 under advanced glycation end product (AGE) stimulation. J Biol Chem 27: 14201-14206, 2004.

18. Campling BG, Pym J, Galbraith PR and Cole SP: Use of the MTT assay for rapid determination of chemosensitivity of human leukemic blast cells. Leuk Res 12: 823-831, 1988.

19. Powell BL, Gregory BW, Kute TE, Morgan TM, Lyerly ES and Capizzi RL: Bromodeoxyuridine incorporation into DNA of human leukemia cells is not concentration dependent Cytometry 11: 438-441, 1990.

20. Huang JS, Guh JY, Chen HC, Hung WC, Lai YH and Chuang LY: Role of receptor for advanced glycation end-product (RAGE) and the JAK/STAT-signaling pathway in AGE-induced collagen production in NRK-49F cells. J Cell Biochem 81: 102-113, 2001.
21. Cai D, Byth KF and Shapiro GI: AZ703, an imidazo[1,2- $\alpha$ ] pyridine inhibitor of cyclin-dependent kinases 1 and 2 , induces E2F-1-dependent apoptosis enhanced by depletion of cyclindependent kinase 9. Cancer Res 66: 435-444, 2006.

22. Agarwal ML, Agarwal A, Taylor WR and Stark GR: p53 controls both the $\mathrm{G}_{2} / \mathrm{M}$ and the $\mathrm{G}_{1}$ cell cycle checkpoints and mediates reversible growth arrest in human fibroblasts. Proc Natl Acad Sci USA 92: 8493-8497, 1995.

23. Martinez J, Georgoff I, Martinez JA and Levine AJ: Cellular localization and cell cycle regulation by a temperature-sensitive p53 protein. Genes Dev 5: 151-159, 1991.

24. Michalovitz D, Halevy O and Oren M: Conditional inhibition of transformation and of cell proliferation by a temperaturesensitive mutant of p53. Cell 62: 671-680, 1990.

25. Mansour SJ, Matten WT, Hermann AS, Candia JM, Rong S, Fukasawa K, et al: Transformation of mammalian cells by constitutively active MAP kinase kinase. Science 265: 966-970, 1994.

26. Brunet A, Pages G and Pouyssegur J: Constitutively active mutants of MAP kinase kinase (MEK1) induce growth factorrelaxation and oncogenicity when expressed in fibroblasts. Oncogene 9: 3379-3387, 1994.

27. Seger R and Krebs EG: The MAPK signaling cascade. FASEB J 9: 726-735, 1995.

28. Chang F, Steelman LS, Lee JT, Shelton JG, Navolanic PM, Blalock WL, et al: Signal transduction mediated by the Ras/ Raf/MEK/ERK pathway from cytokine receptors to transcription factors: potential targeting for therapeutic intervention. Leukemia 17: 1263-1293, 2003.

29. Hsia CY, Cheng S, Owyang AM, Dowdy SF and Liou HC: C-Rel regulation of the cell cycle in primary mouse B lymhocytes. Int Immunol 14: 905-916, 2002

30. Guttridge DC, Albanese C, Reuther JY, Pestell RG and Baldwin AS Jr: NF-kappa B controls cell growth and differentiation through transcriptional regulation of cyclin D1. Mol Cell Biol 19: 5785-5799, 1999.

31. Hinz M, Krappmann D, Eichten A, Heder A, Scheidereit C and Strauss M: NF-kappa B function in growth control: regulation of cyclin D1 expression and G0/G1-to-S-phase transition. Mol Cell Biol 19: 2690-2698, 1999. 